\title{
Neurofibromatosis Type 1 Gene Product (Neurofibromin) Associates with Microtubules
}

\author{
Paula E. Gregory, ${ }^{1}$ David H. Gutmann, ${ }^{1}$ Anna Mitchell, ${ }^{1}$ Soochul Park, ${ }^{1}$ Mark Boguski, ${ }^{2}$ \\ Tyler Jacks, ${ }^{3}$ Deborah L. Wood, ${ }^{1}$ Richard Jove, ${ }^{1}$ and Francis S. Collins ${ }^{1}$

\begin{abstract}
${ }^{1}$ The Departments of Internal Medicine, Human Genetics, Neurology and Microbiology and Immunology, The University of Michigan Medical Center and The Howard Hughes Medical Institute, The University of Michigan, Ann Arbor, Michigan 48109; ${ }^{2}$ National Center for Biotechnology Information, NIH, Bethesda, Maryland 20894; and ${ }^{3}$ Center for Cancer Research, Massachusetts Institute of Technology, 40 Ames Street, Cambridge, Massachusetts 02139
\end{abstract}

Received 19 February 1993

\begin{abstract}
The neurofibromatosis type 1 (NF1) gene was recently identified by positional cloning and found to encode a protein with structural and functional homology to mammalian and yeast GTPase-activating proteins (GAPs). Using antibodies directed against the NFI gene product, a protein of $\sim 250 \mathrm{kDa}$ was identified and termed neurofibromin. Double-indirect immunofluorescent labeling with anti-neurofibromin and anti-tubulin antibodies demonstrates that neurofibromin associates with cytoplasmic microtubules. Immunoblotting of microtubule-enriched cytoplasmic fractions, using antibodies generated against neurofibromin, shows that neurofibromin copurifies with microtubules. When portions of neurofibromin are expressed in Sf 9 insect cells they associate with polymerized microtubules; furthermore, the critical residues for this interaction reside within the GAP-related domain of neurofibromin. The unexpected association of neurofibromin with microtubules suggests that neurofibromin is involved in microtubule-mediated intracellular signal transduction pathways.
\end{abstract}

\section{INTRODUCTION}

Neurofibromatosis type 1 (NF1), or von Recklinghausen neurofibromatosis, is one of the most common autosomal dominant disorders in man. It is characterized by abnormalities that primarily affect tissues derived from the neural crest, including multiple neurofibromas, cafe-au-lait spots, axillary freckling, Lisch nodules, distinct bony lesions, and optic nerve glioma (1). Early linkage analysis demonstrated that the locus for $N F 1$ resided on chromosome $17(2,3)$. The identification of two NF1 patients with chromosome 17 translocations expedited the identification of the gene for this disease (4-6). Further chromosomal and cDNA walking culminated in the construction of the entire $N F 1$ coding sequence (7). Analysis of the 2818 amino acid open reading frame demonstrated sequence similarity between a small central portion of NFI and a family of GTPaseactivating proteins (GAPs) (8). Functional homology to GAP has been demonstrated using biochemical assays of RAS-GTP hydrolysis as well as by functional complementation studies in yeast (9-11).

The protein product of the NF1 locus has recently been identified $(12,13)$. Using antibodies generated against fusion proteins and synthetic peptides, a unique $250-\mathrm{kDa}$ protein was found in all tissues and cell lines 
examined; however, the highest levels of expression were in brain, spleen, and kidney. The NF1 gene product was originally termed NF1-GAP-related protein (NF1GRP) to emphasize the relationship between $N F 1$, mammalian GAP (14), and the yeast IRAI and IRA2 genes (15), but is now called neurofibromin. This protein was localized to the cytoplasm by differential centrifugation and by glycerol gradients (13). Furthermore, unlike GAP, which is phosphorylated on tyrosine residues in response to growth factor stimulation, neurofibromin is instead heavily phosphorylated on serine and threonine residues (16). In order to identify the subcellular localization of neurofibromin, indirect immunofluorescent analyses were performed using anti-neurofibromin antibodies. This paper describes the unexpected association of neurofibromin with microtubules, suggesting that neurofibromin may be involved in microtubule-mediated signal transduction pathways.

\section{MATERIALS AND METHODS}

Generation of Antibodies. Anti-neurofibromin antibodies were produced by hyperimmunizing rabbits with either the synthetic G peptide (residues 1400-1419 of the fulllength NF1 translated cDNA sequence) conjugated to keyhole limpet hemoglobin (KLH; 13:1 coupling ratio) or fusion proteins containing portions of the NF1 cDNA subcloned into the pMAL expression vector system (New England BioLabs) (17). The generation of the $\mathrm{pMAL} . \mathrm{B} 3 \mathrm{~A}$ antiserum has been previously described (12). Antiserum was precipitated in $33 \%$ ammonium sulfate and extensively dialyzed against PBS. After dialysis, the fusion protein antiserum was absorbed twice overnight with pMAL.c fusion protein immobilized onto nitrocellulose filters to remove antibodies directed against the maltose binding protein portion of the fusion protein. The mouse monoclonal GAP antibody (B4F8) was purchased from Santa Cruz Biotechnology.

Immunofluorescence. Cells grown on glass cover slips were rinsed with PBS and then fixed in $-20^{\circ} \mathrm{C}$ methanol for $5 \mathrm{~min}$. Cells were subsequently rehydrated with PBS. Primary antibodies (anti-neurofibromin or mouse monoclonals) were diluted $1: 100$ in DMEM media containing $10 \%$ fetal calf serum and incubated for $1 \mathrm{~h}$ at $37^{\circ} \mathrm{C}$ in a humidified chamber. The cover slips were then rinsed in PBS and secondary antibodies [affinity-purified fluorescein-conjugated goat anti-rabbit or rhodamine-conjugated goat anti-mouse (Boehringer Mannheim)] were diluted 1:200 in media and incubated on cover slips for $30 \mathrm{~min}$ at $37^{\circ} \mathrm{C}$ and then washed three times in PBS. Nuclei were counterstained with propidium iodide (2 $\mathrm{ng} / \mathrm{ml}$ ) for $3 \mathrm{~min}$. Cover slips were washed twice with PBS and mounted in Citifluor. Photomicrographs were taken with a Zeiss Axiophot microscope using Kodak T-Max 400 or Ektachrome 400 film.

Double-labeled samples were analyzed using a Nikon Optiphot microscope mounted to a laser-scanning confocal imaging system (Bio-Rad 600). We obtained a z-series from computer assisted images taken simultaneously from two channels.

Construction of the Homozygous NF1 Knockout Cell Lines. Using gene targeting techniques on embryonic stem (ES) cells, the mouse homolog of the human NF1 gene exon 31 was interrupted by the bacterial neomycinresistance gene, as described by Thomas and Capecchi (18). The targeting efficiency was high, with approximately one homologous recombination per 50 G418-resistant cells. Heterozygous ES cell clones were used to construct germline chimeras that were subsequently crossed to produce homozygous NF1 knockout mice ( $\mathrm{T}$. Jacks, in preparation). Embryonic fibroblast cell lines were established from homozygous NF1 knockout mice $(182.193-\mathrm{H})$ and from littermates that were 
homozygous for the wild-type NF1 gene (182.193-F).

Cell Culture. All mammalian cell lines

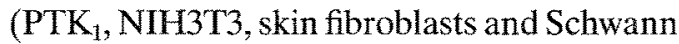
cells) were maintained in DMEM supplemented with $10 \%$ fetal calf serum in a $5 \%$ $\mathrm{CO}_{2}$ atmosphere; however, $\mathrm{Sf} 9$ insect cells were grown in complete Grace's insect cell media at $28^{\circ} \mathrm{C}$ without $\mathrm{CO}_{2}$.

Immunoblotting. Microtubule preparations were generated by standard microtubule cycling methods (19). Protein, $100 \mu \mathrm{g}$, from supernatant and enriched microtubule fractions ( $25 \mu \mathrm{g}$ protein from Sf9 cells) was boiled in standard Laemmli loading buffer, separated by $7.5 \%$ SDS-PAGE, and transferred onto Immobilon filters (Millipore) in $50 \mathrm{mM}$ Tris $\mathrm{HCl}, 380 \mathrm{mM}$ glycine, and $10 \%$ methanol for $2 \mathrm{~h}$ at $80-90 \mathrm{~V}$. Membranes were blocked for $2 \mathrm{~h}$ in $5 \%$ Blotto-TBST $(20$ $\mathrm{mM}$ Tris $\mathrm{HCl}, \mathrm{pH} 7.5,150 \mathrm{mM} \mathrm{NaCl}, 0.05 \%$ Tween-20) prior to overnight incubation with $1 \mu \mathrm{g} / \mathrm{ml}$ anti-neurofibromin antibody or $1: 1000$ dilution of $\beta$-tubulin mouse monoclonal antibody (Sigma). Secondary alkaline phosphatase-conjugated anti-mouse (1:2500 dilution; Promega) or anti-rabbit (1:3000 dilution; Biorad) antibodies were incubated for $1 \mathrm{~h}$ and filters were developed using 5-bromo-4-chloro-3-indolyl phosphate with nitroblue tetrazolium (20).

Preparation of Viral Stocks. Fragments of the NFI gene were cloned into the NheI site of the baculovirus transfer vector pBlueBac (Invitrogen). The construct with the GAP-related domain (GRD) consisted of the $1.2-\mathrm{kb}$ fragment between nucleotides 3368 and 4608 , while the HF3A fragment extends from nucleotide -112 through 4842 (numbering is relative to +1 being the start of translation) (7). The p120-GAP construct contained a $4.3-\mathrm{kb}$ fragment of the bovine p120-GAP gene (21). Viral stocks were prepared as previously described (22), infected cells were lysed and the lysate was immunoblotted with neurofibromin or p120-
GAP antibodies to verify that the correct protein was being produced.

Infection of Cells with Virus. Sf9 cells, $1.8 \times 10^{7}$, were plated and allowed to attach overnight. The cells were then infected with virus at a multiplicity of infection of six. After infection, the viral solution was removed and replaced with complete media. The cells were then cultured at $28^{\circ} \mathrm{C}$ for $48 \mathrm{~h}$.

Ion Exchange Chromatography. Tubulin and MA.Ps were separated using the method described by Vallee (19). Thrice-cycled microtubule preparations were applied in $0.25 \mathrm{M}$ $\mathrm{NaCl}-$ Pipes-HCl, $\mathrm{pH}$ 6.6, $1 \mathrm{mM}$ EDTA, 1 $\mathrm{mM} \mathrm{MgSO}_{4}$, and $1 \mathrm{mM} \mathrm{GTP} \mathrm{(PEMG)} \mathrm{onto} \mathrm{a}$ DEAE Sephadex A-50 column. Fractions that eluted at $0.25 \mathrm{M} \mathrm{NaCl}-\mathrm{PEMG}$ and at 0.5 $\mathrm{M} \mathrm{NaCl}-\mathrm{PEMG}$ were collected separately and stored at $-70^{\circ} \mathrm{C}$ in PEM with $1 \mathrm{mM}$ GTP. One hundred micrograms of each fraction were loaded onto $7.5 \%$ SDSpolyacrylamide gels and immunoblotted as previously described.

\section{RESULTS}

Immunofluorescent Subcellular Localization of Neurofibromin. In order to broaden our understanding of neurofibromin function, we investigated the subcellular localization of neurofibromin using indirect immunofluorescence with antibodies. Figure $1 \mathrm{~A}$ and $\mathrm{B}$ compares the preimmune and immune staining, respectively, of NIH 3 T3 cells with a polyclonal antibody generated against the pMAL.B3A fusion protein (residues 27462818). The immune staining consistently shows that neurofibromin is concentrated in the perinuclear region of the cell but can also be visualized extending into the cytoplasm. The staining reaction could be inhibited by preincubation with the purified fusion protein (Fig. 1C), thus demonstrating its specificity. This specificity was further confirmed using murine embryonic fibroblasts containing a homozygous targeted disruption of the NF1 gene. These cells showed only nonspe- 

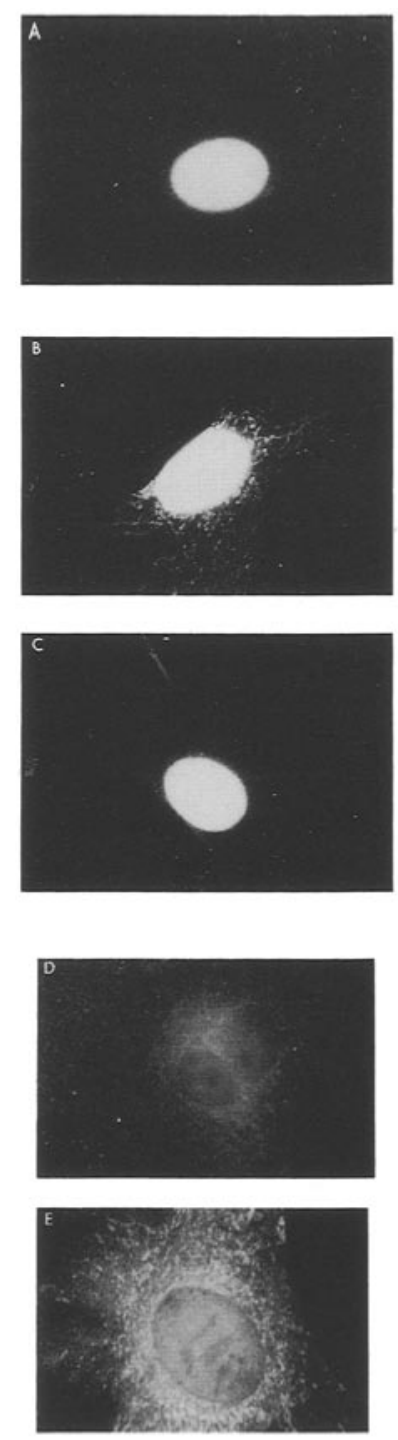

Fig. 1. Indirect immunofluorescent analysis demonstrates the specificity of anti-neurofibromin antibodies using NIH3T3 and NF1-knockout mouse cells. Preimmune rabbit sera gave diffuse, nonspecific background staining (A); while the immune sera from that rabbit showed a distinct cytoplasmic staining pattern (B). The staining could be inhibited by preincubation with purified antigen, in this case the pMAL.B3A fusion protein (C). All cell nuclei in A-C were counterstained with propidium iodide. Embryonic fibroblasts from homozygous knockout mice stained with anti-neurofibromin antibodies exhibit faint, diffuse, nonspecific background staining (D), while cells from wild-type littermates showed a distinct punctate and fibrillar cytoplasmic staining pattern (E). cific, background staining (Fig. 1D), while wild-type littermate cells showed a cytoplasmic staining pattern similar to NIH 3 T3 cells (Fig. 1E). Moreover, analysis of these two cell types using preimmune sera showed no specific staining in either cell line (data not shown).

Association of Neurofibromin with Cytoskeletal Elements. Immunofluorescent analysis of rat kangaroo fibroblasts $\left(\mathrm{PTK}_{1}\right)$ demonstrated a fine fibrillar cytoplasmic staining pattern. The fibrillar staining pattern was similar to that of a cytoskeletal element. Double-label indirect immunoffuorescence analyzed by laser scanning confocal microscopy demonstrated that neurofibromin is localized within punctate perinuclear bodies and along microtubules (Fig. 2). A z-series of $0.5-\mu \mathrm{m}$ images showed that neurofibromin (Fig. 2A) and cytoplasmic microtubules (tubulin; Fig. 2B) were associated throughout the cell. Interestingly, neurofibromin was never observed in association with either spindle microtubules or midbodies. Furthermore, the staining pattern showed no relation to actin filaments in any of the cells examined (data not shown). An antibody generated against a peptide from a spatially different portion of the molecule $(\mathrm{H} ; 12)$ also decorated the microtubules (data not shown).

To further characterize the relationship between neurofibromin and microtubules, cells were treated with antimitotic drugs that cause the disassembly of most microtubules. Exposure of cells to colcemid, nocodazole, or griseofulvin resulted in the dissolution of cytoplasmic microtubules and the simultaneous disaggregation of neurofibromin staining (data not shown). When cells treated with colcemid were allowed to recover and the microtubules had reassembled, neurofibromin also returned to its original localization pattern (data not shown).

Despite the punctate appearance of the neurofibromin immunofluorescence pattern, these antibodies did not appear to be recognizing any particular cellular organelle. 

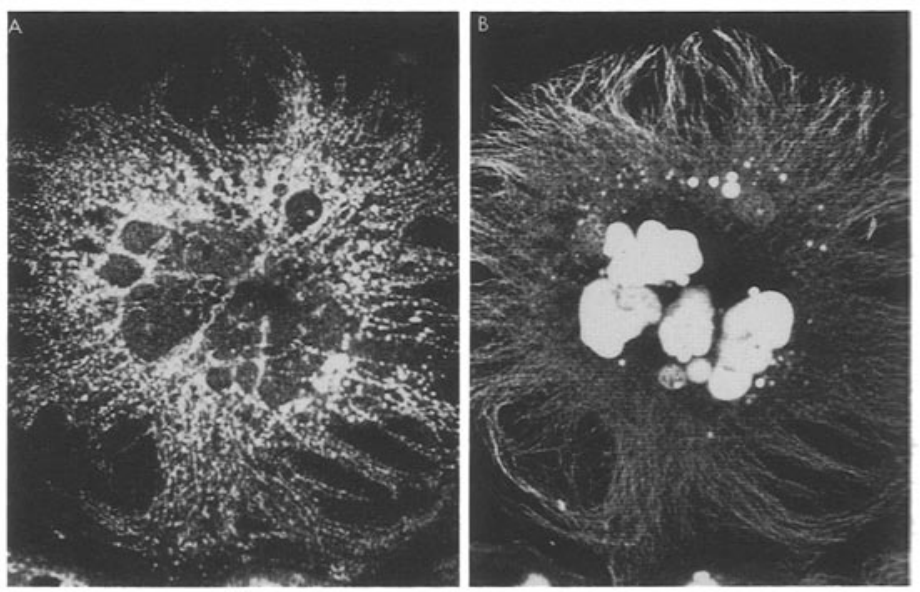

Fig. 2. Neurofibromin colocalizes with cytoplasmic microtubules by double-label indirect immunofluorescence. The similarity between the staining pattern of neurofibromin and microtubules can best be appreciated with double immunofluorescent staining. The same PTK cell was stained with both anti-neurofibromin antibodies (pMAL.B3A antíserum) and monoclonal $\beta$-tubulin antibodies (Sigma). Neurofibromin was detected with an FITC-labeled secondary antibody $(A)$, while the microtubules were detected with a rhodamine-labeled secondary antibody $(B)$. $A$ series of $0.5-\mu \mathrm{m}$ optical sections was obtained using laser scanning confocal microscopy. The image demonstrates that neurofibromin localization is aligned with microtubules throughout the cell. This association is particularly evident in areas of microtubule bundles. The nuclear counterstain is apparent on the rhodamine channel (B).

To determine whether the neurofibromin antibodies cross-reacted with a protein within an organelle, primary human fibroblasts were labeled with antibodies against mitochondria (Chemicon), Golgi complex (Chemicon), and endoplasmic reticulum and the pMAL.B3A neurofibromin antibody. None of the organelle-specific antibodies recognized the same structures as the pMAL.B3A antibody (data not shown).

Neurofibromin is Enriched in MicrotubuleContaining Preparations. To provide biochemical confirmation of the indirect immunofluorescence observation that neurofibromin associates with microtubules, in vitro assembled microtubule preparations from rat brain were examined by western immunoblotting. As shown in Fig. 3A, enriched microtubule, but not supernatant, fractions contain neurofibromin and $\beta$-tubulin. Immunoblotting of identical PVDF membranes with monoclonal antibodies directed against MAP1 or MAP2 demonstrated similar copurification patterns as those seen with neurofibromin (data not shown). However, p120-GAP was not enriched in the microtubule fractions and could be detected in both the supernatant and microtubule fractions (data not shown).

Ion exchange chromatography was performed in order to determine whether neurofibromin could be eluted from a DEAESephadex A-50 column in the same fashion as other proteins which associate with microtubules. Figure 3B shows that both neurofibromin and MAP2 elute from microtubule preparations with $0.25 \mathrm{M} \mathrm{NaCl}$ by DEAE ion exchange chromatography, whereas tubulin is eluted with $0.5 \mathrm{M} \mathrm{NaCl}$.

Localization of Domain Responsible for Neurofibromin-Microtubule Association. In an effort to determine which region(s) of neurofibromin associate(s) with microtubules, portions of the NF1 gene were expressed in Sf9 insect cells and assayed for their ability to copurify with insect cell microtubules by in vitro microtubule assembly. As can be seen in Fig. 4A, both the GAP-related domain, as well as the amino terminal portion of neurofibromin (which contains the GRD), 
A

S3 MI3 MI2 MI1 S2 S1

NEUROFIBROMIN

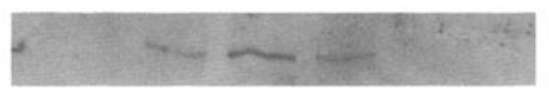

$\beta$-TUBULIN

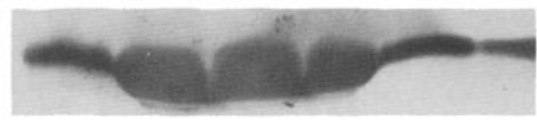

B

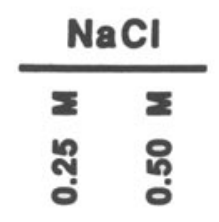

NEUROFIBROMIN

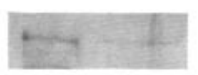

MAP2

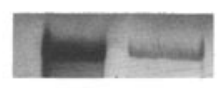

$\beta$-TUBULIN

Fig. 3. Immunoblotting of microtubule-enriched fractions demonstrates the presence of neurofibromin and its separation by ion-exchange chromatography. (A) One hundred micrograms of protein from either the supernatant (S) or microtubule-containing (MT) fractions obtained by repeated cycling of rat brain homogenates were separated by $7.5 \%$ SDS-PAGE prior to transfer to PVDF membranes and immunoblotting with neurofibromin antibodies (G1; 1:200) and $\beta$-tubulin antibodies $(1: 1000)$. MT1 = microtubule fractions; $S 1=$ supernatant fraction. (B) One hundred micrograms of protein from either the $0.25 \mathrm{M} \mathrm{NaCl}$ fractions or the $0.5 \mathrm{M} \mathrm{NaCl}$ fractions from thrice-cycled rat brain microtubules were separated by $7.5 \%$ SDS-PAGE prior to transfer to PVDF membranes and immunoblotting with neurofibromin antibodies (1:200), MAP2 antibodies (1:1000), and $\beta$-tubulin antibodies (1:1000). Development was performed using anti-mouse or anti-rabbit alkaline phosphatase-conjugated secondary antibodies as described in the Materials and Methods.

copurify with polymerized microtubules during cycling. This is in contrast to the results obtained from microtubule cycling experiments using Sf9 cells expressing full-length GAP (Fig. 4B), in which p120-GAP was enriched in the supernatant but not the microtubule fraction. Coexpression of neurofibromin (GRD or HF3A) and p120-GAP in Sf9 cells did not alter their respective microtubule localization patterns (data not shown).

\section{DISCUSSION}

The recent cloning of the gene for von Recklinghausen neurofibromatosis has made it possible to design experiments that analyze the function of its gene product. The genera- 


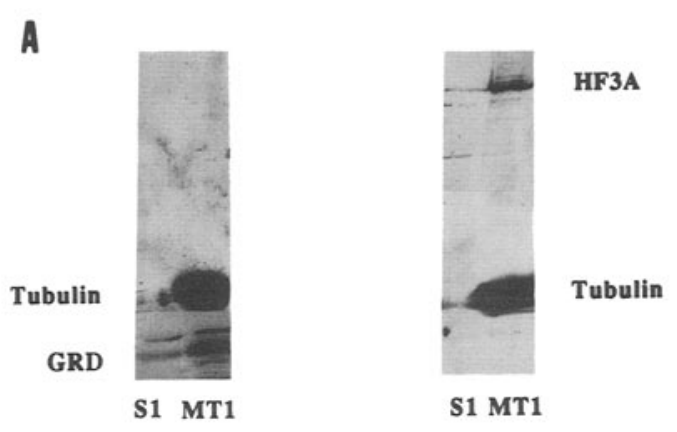

B

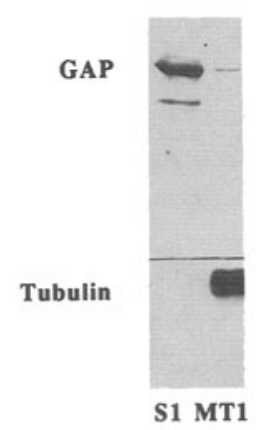

Fig. 4. Immunoblotting of microtubule-enriched fractions in Sf9 insect cells expressing neurofibromin demonstrates the presence of neurofibromin. Protein (25 $\mu \mathrm{g}$ ) was analyzed from the supernatant (S1) or microtubule (MT1) fractions from one cycle of microtubule assembly of Sf9 cell lysates. Protein from Sf9 cells that express either a portion of the neurofibromatosis gene (A) or p120-GAP (B) were separated by $7.5 \%$ SDS-PAGE. After transfer to PVDF membranes, immunoblotting was performed with $\beta$-tubulin monoclonal antibody $(1: 1000)$, rabbit anti-neurofibromin antibody $(1 \mu \mathrm{g} / \mathrm{ml})$, or monoclonal GAP antibody (1:1000). The portions of the neurofibromin protein associated with the microtubule pellet while GAP remained in the supernatant. GRD $=$ GAP-related domain (amino acids 1123-1536); HF3A = amino terminal portion of neurofibromin (amino acids $1-1614$ ).

tion of antibodies that recognize the $N F 1$ gene product (neurofibromin) was an important step toward understanding its function(s). Using double-indirect immunofluorescence, neurofibromin has been localized to the cytoplasmic compartment of the cell; furthermore, double-labeling shows that it associates with microtubules. The postulated association of neurofibromin with microtubules is further supported by in vitro microtu- bule assembly experiments. Further confirmation of this association is provided by the demonstration that portions of neurofibromin expressed in insect Sf9 cells likewise associate with microtubules. The experiments with baculovirus-expressed neurofibromin fragments indicate that the residues responsible for microtubule interaction reside within the GAP-related domain segment. These data strongly suggest that there are specific interactions between neurofibromin and microtubules. Similar results have been obtained using baculovirus-expressed full-length neurofibromin in Sf9 cells (23).

Although neurofibromin associates and copurifies with microtubules, it is premature to classify it as a microtubule-associated protein (MAP) (24-26). To this end, our neurofibromin antibodies do not recognize MAP1, MAP2, or tau (data not shown). The immunofluorescent staining pattern suggests that the microtubules are decorated by aggregates of neurofibromin. The possibility that neurofibromin is part of a larger complex or even a small organelle has not been ruled out. Some cellular organelles can copurify with microtubules in the same fashion as MAPs. However, the staining pattern obtained with neurofibromin antibodies does not resemble the pattern obtained with antibodies directed against mitochondria, Golgi apparatus, or endoplasmic reticulum. It is important to distinguish between bona fide MAPs, which directly interact with and play an intrinsic role in stabilizing microtubules or facilitating microtubulemediated transport, and other proteins that associate with microtubules but lack these properties. Further studies are needed to clearly define the biochemical nature of neurofibromin's interaction with microtubules before neurofibromin can be definitively classified as a MAP. However, the present results suggest that neurofibromin, unlike p120-GAP, has a physical association with microtubules, and this association may 
have important implications in understanding its role in signal transduction pathways.

The association of MAPs with tubulin is mediated by at least two different motifs. MAP2 (27), tau (28), and bovine adrenal 190-kDa MAP (29) contain a specific 18 amino acid sequence (containing Pro-GlyGly and repeated 1-4 times) that is a key component of the tubulin binding domain. MAP1B contains no such domain, however, and its tubulin binding has been defined as a basic region of the protein containing multiple copies of the motif KKEE or KKE I/V (30). The molecular basis for the association between neurofibromin and tubulin may be quite different than that for MAP1B, MAP2, or tau, since no homology to the 18 amino acid repeat or the KKEE or KKE I/V motifs are present in the amino acid sequence of neurofibromin. However, careful sequence comparison reveals a 20 amino acid domain within neurofibromin, which is homologous to a segment near the C-terminal end of both MAP2 and tau (Fig. 5). Tau contains a central serine (Ser-409) within this homologous region that has been shown to be a substrate for phosphorylation (31). Furthermore, the phosphorylated form no longer binds to microtubules. The GRD construct expressed in baculovirus did not include the 20 amino acid motif; therefore, this serinecontaining region is not required for association with microtubules. However, the possibility that neurofibromin may have a role in regulation of this interaction cannot be excluded at this time.

Our data demonstrate that neurofibromin is a GAP that associates with microtubules and suggests several hypotheses that explain its function, any of which would give this protein a unique role in regulation of cell division and/or differentiation. One model, which fits an "upstream" view of ras-GAP interactions (32), suggests that neurofibromin activity is regulated via phosphorylation by MAP kinases, such as the ERK family (33, 34). In this model, neurofibromin would be active as a GAP while associated with

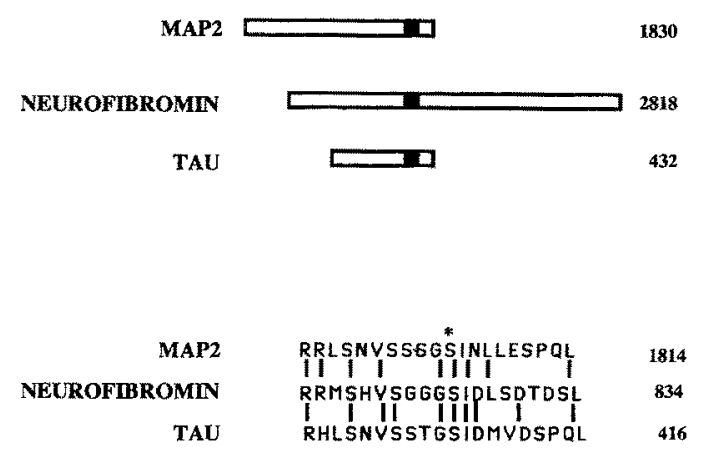

Fig. 5. A small region of neurofibromin shares a potential serine phosphorylation sequence with tau and MAP2. Local sequence similarities among MAP2, neurofibromin, and tau were identified using the BLAST3 program (38). The MACAW program (39) was used to estimate the significance of this three-way alignment and the probability that the three sequences are related by chance is $-10^{-12}$. To assess the specificity of this 20-residue segment, a quantitative search "profile" (40) was constructed and used to search the protein sequence data bases using the PROFILESEARCH program (Genetics Computer Group, Inc.). This profile identified MAP2, neurofibromin, and tau with $Z$-value scores $>17$. All other known proteins gave $Z$-value scores $<10$. Phosphorylation of the central serine residue has been shown to play an important role in interactions between tau and microtubules (31). The total number of amino acids in each protein is indicated in the top portion of the figure, which also indicates the location (black box) of the motif. In the bottom portion, the number indicates the residue of the rightmost leucine for each protein.

microtubules, keeping ras in its inactive GDP-bound form and inhibiting cell division. After phosphorylation by a MAP kinase (perhaps on Ser-825; see Fig. 5), neurofibromin might dissociate from microtubules and its GAP activity would be reduced or altered. As suggested by recent experiments, the association of neurofibromin with tubulin may reduce its ability to function as a GAP (23). This would provide a very different pathway for ras regulation than that of mammalian p120-GAP, which is downregulated by tyrosine phosphorylation mediated through its $\mathrm{SH} 2$ and $\mathrm{SH} 3$ domains (35).

A "downstream" model for ras-GAP interactions (32) would suggest that neurofibromin is induced by the process of ras-GTP to ras-GDP conversion to transmit a differentiation signal through its influence on microtubule organization. Recently, it has been 
shown that both cessation of proliferation and extension of neurites in the retinoic acid-induced cell line P19 are dependent upon MAP2 expression (36). Could neurofibromin play a similar role, and if so, could its loss by mutation in neurofibromatosis lead to continued cell division and failure to differentiate (i.e., tumor formation)? Regardless of which of these models proves to have merit, the demonstration that neurofibromin is a GAP that associates with microtubules is an unexpected turn of events. Given the large size of the protein (7) and its high degree of cross-species conservation (37), it will not be surprising if additional functions are defined with further analysis.

\section{ACKNOWLEDGMENTS}

Paula E. Gregory and David H. Gutmann contributed equally to this work. We would like to thank Dr. Ron Balczon for providing PTK $_{1}$ cells, Dr. David Bole for providing anti-endoplasmic reticulum antibodies, Dr. Lester Binder for providing monoclonal MAP antibodies who along with Dr. Michael Welsh gave us helpful discussions and critical review of our results. We are grateful to Dr. Brian Athey for his assistance with the confocal analyses. We also recognize and appreciate the intellectual contributions of Drs. Margaret R. Wallace, Lone B. Andersen, Susan WilsonGunn, Douglas Marchuk, and Theresa Strong. This work was supported in part by a grant from the National Institutes of Health (NS23410). F.S.C. is an investigator of The Howard Hughes Medical Institute. D.H.G. is supported by a Clinical Investigator Award (NS01590) from NINDS.

\section{LITERATURE CITED}

1. Riccardi, V.M., and Eichner, J.E. (1986). Neurofibromatosis: Phenotype, Natural History and Pathogenesis, (Johns Hopkins University Press, Baltimore).

2. Collins, F.S., Ponder, B.A.J., Seizinger, B.R., and Epstein, C.J. (1989).Am. J. Hum. Genet. 44:1-5.
3. Collins, F.S., O'Connell, P.S., Ponder, B.A.I., and Seizinger, B.R. (1989). Trends Genet. 5:217-221.

4. Wallace, M.R., Marchuk, D.A., Andersen, L.B., Letcher, R.y Odeh, H.M., Saulino, A.M., Fountain, J.W., Brereton, A., Nicholson, J, Mitchell, A.L., Brownstein, B.H., and Collins, F.S. (1990). Science 249:181-186.

5. Viskochil, D., Buchberg, A.M., Xu, G., Cawthon, R.M., Stevens, J., Wolff, R.K., Culver, M., Carey, J.C., Copeland, N.G., Jenkins, N.A., White, R., and O'Connell, P. (1990). Cell 62:187-192.

6. Cawthon, R.M., Weiss, R., Xu, G., Viskochil, D., Culver, M., Stevens, J., Robertson, M., Dunn, D., Gesteland, R., O'Connell, P., and White, R. (1990). Cell 62:193-203.

7. Marchuk, D.A., Saulino, A.M., Tavakkol, R., Swaroop, M., Wallace, M.R., Andersen, L.B., Mitchell, A.L., Gutmann, D.H., Boguski, M., and Collins, F.S. (1991). Genomics 11:931-940.

8. Xu, G., O'Connell, P., Viskochil, D., Cawthon, R., Robertson, M., Culver, M., Dunn, D., Stevens, J, Gesteland, R., White, R., and Weiss, R. (1990). Cell 62:599-608.

9. Ballester, R., Marchuk, D., Boguski, M., Saulino, A., Letcher, R., Wigler, M., and Collins, F. (1990). Cell 63:851-859.

10. Xu, G., Lin, B., Tanaka, K., Dunn, D., Wood, D., Gesteland, R., White, R., Weiss, R., and Tamanoi, F. (1990). Cell 63:835-841.

11. Martin, G.A., Viskochil, D., Bollag, G., McCabe P.C, Crosier, W.J., Haubruck, H., Conroy, L., Clark, R., O'Connell, P., Cawthon, R.M., Imnis, M., and McCormick, F. (1990). Cell 63:843-849.

12. Gutmann, D.H., Wood, D.L., and Collins, F.S. (1991). Proc. Natl. Acad. Sci. U.S.A. 88:9658-9662.

13. DeClue, J., Cohen, B.D., and Lowy, D.R (1991). Proc. Natl. Acad. Sci. U.S.A. 88:9914-9918.

14. Vogel, U.S., Dixon, R.A.F., Schaber, M.D., Diehl, R.E., Marshall, M.S., Scolnick, E.M., Sigal, I.S., and Gibbs, J.B. (1988). Nature 335:90-93.

15. Tanaka, K., Nakafuku, M., Satoh, T., Marshall, M.S., Gibbs, J.B., Matsumoto, K., Kaziro, Y., and Toh-e, A. (1990). Cell 60:803-807.

16. Gutmann, D.H., Basu, T., Gregory, P., Wood, D., Downward, J., and Collins, F. (1992). Neurology 42:183 -184A.

17. Studier, F.W., Rosenberg, A.H., Dunn, J.J., and Dubendorf, J.W. (1990). Methods Enzymol. 185:60 89.

18. Thomas, K.R., and Capecchi, M.R. (1987). Cell 51:503-512.

19. Vallee, R.B. (1986). Methods Enzymol. 134:89-104,

20. Harlow, E., and Lane, D. (1988). Antibodies: $A$ Laboratory Manual, (Cold Spring Harbor Laboratory, Cold Spring Harbor, New York), pp. 421-470.

21. Park, S., Marshall, M.S., Gibbs, J.B, and Jove, R. (1992). J. Biol Chem. 267:11612-11618.

22. Piwnica-Worms, H. (1988). In Current Protocols in Molecular Biology, (eds.) Ausubel, F.M., Brent, R. Kingston, R.E., Moore, D.D., Seidman, J.G., Smith, J.A., and Struhl, K. (John Wiley and Sons, New York), Chapter 16.

23. Bollag, G., McCormick, Fy, and Clark, R. (1993). $E M B O J$. (in press). 
24. Matus, A. (1990). Curr. Opin. Cell Biol. 2:10-14.

25. Olmsted, J.B. (1986). Annu. Rev. Cell. Biol. $2: 421-457$

26. Olmsted, J.B. (1991). Curr. Opin. Cell Biol. 3:52-58.

27. Lewis, S.A., Wang, D., and Cowan, N.J. (1988). Science 242:936-939.

28. Lee, G., Cowan, N., and Kirschner, M. (1988). Science 239:285-288.

29. Aizawa, H., Emori, Y., Mori, A., Murofushi, H., Sakai, H., and Suzuki, K. (1991). J. Biol Chem. 266:9841-9846.

30. Noble, M., Lewis, S.A., and Cowan, N.J. (1989). J. Cell. Biol. 109:3367-3376.

31. Steiner, B., Mandelkow, E-M., Biernat, J., Gustke, N., Meyer, H.E., Schmidt, B., Mieskes, G., Soling, H.D., Drechsel, D., Kirschner, M.W., Goedert, M., and Mandelkow, E. (1990). EMBO J. 9:3539-3544.

32. Hall, A. (1990). Cell 61:921-923.
33. Tsao, H., Aletta, J.M., and Greene, L.A. (1990). J. Biol. Chem. 265:15471-15480.

34. Boulton, T.G., Nye, S.H., Robbins, D.J., Ip, N.Y., Radziejewska, E., Morgenbesser, S.D., DePinho, R.A., Panayotatos, N., Cobb, M.H., and Yancopoulos, G.D. (1991). Cell 65:663-675.

35. Downward, J., Graves, J.D., Warne, P.H., Rayter, S., and Cantrell, D.A. (1990). Nature 346:719-723.

36. Dinsmore, J.H., and Solomon, F. (1991). Cell 64:817-826.

37. Buchberg, A.M., Cleveland, L.S., Jenkins, N.A., and Copeland, N.G. (1990). Nature 347:291-295.

38. Altschul, S.F., and Lipman, D.J. (1990). Proc. Natl. Acad. Sci. U.S.A. 87:5509-5513.

39. Schuler, G.D., Altschul, S.F., and Lipman, D.J. (1991). Proteins Struct. Func. Genet. 9:180-190.

40. Gribskov, M., Luthy, R., and Eisenberh, D. (1990). Methods Enzymol. 183:146-159. 